\title{
Panel Data Analysis of Public and Private Debt and House Price Influence on GDP in the European Union Countries
}

\author{
Vytautas Snieska ${ }^{1}$, Daiva Burksaitiene ${ }^{2}$
}

\author{
Kaunas University of Technology \\ K. Donelaicio st. 73, LT-44029, Kaunas, Lithuania \\ E-mail.vytautas.snieska@ktu.lt
}

Vilnius Gediminas Technical University

Sauletekio al. 11, LT-10223 Vilnius, Lithuania

E-mail.daiva.burksaitiene@vgtu.lt

cross $^{\text {ref }}$ http://dx.doi.org/10.5755/j01.ee.29.2.20000

\begin{abstract}
The panel data analysis of the influence of change in real public debt, real private debt, and deflated house prices on the GDP in selected European countries is performed. Least squares and autoregressive AR(p) model were used with crosssection and period both fixed by dummy variables. The research has confirmed strong negative influence of public debt with zero, one and two year's lags as an independent variable on the GDP as the dependent variable. This is not surprising having in mind limited functionality of the European central bank as a lender of the last resort for the countries of the monetary union, that is, for the most of the analysed countries. This finding also confirms the necessity of the transformation of the European Monetary Union to the European Financial Union. Private debt has definite positive influence on the GDP as the dependent variable. It was confirmed by measuring this influence with zero, one and two and three years lags, but this positive influence was 2-3 times lower than the negative influence of public debt on the GDP. House prices unlagged have similar absolute value of positive influence on the GDP coefficient as the absolute value of the negative influence of lagged public debt, according to the regression coefficients received. However, house prices, leading by 2 years, have negative influence on the GDP, but this influence is almost 5 times weaker than the negative influence of unlagged public debt.
\end{abstract}

Keywords: Panel Data Analysis; House Prices; Public Debt; Private Debt; Euro Zone; GDP Growth.

\section{Introduction}

Influence of debt on the growth rate has been "hot topic" for macroeconomists lately. Growth of the economy, which is measured by the growth rate of the GDP, depend not only on the productivity, innovations and labour used in production process or other production factors but also depend on the investments in the country's economy and depend on the aggregate demand conditions. If products are produced, but not sold, they may become not as an input to GDP, but as waste. Widely used equation $\mathrm{GDP}=\mathrm{C}+\mathrm{I}+\mathrm{G}+\mathrm{NX}$, where $\mathrm{C}$ is consumption, $\mathrm{I}$ - investments, $\mathrm{G}$ - government expenses, NX - nett export, doesn't consider the role of financial variables, which are extremely important for generating aggregate demand and the development of business cycles.

Financial variables, influencing GDP growth, are public debt, private debt and house prices. They were extensively discussed in literature

Seminal papers of Reinhart and Rogoff (2010) gave birth for a vast amount of literature on the problem of the interaction between public debt and economic growth.

Reinhart C., Reinhart V. and Rogoff (2012) have analysed advanced economies and found that situations when gross public debt exceeds 90 percent of nominal GDP are correlated with lower growth which in most cases had persisted more than ten years. In half of these cases the decline of growth rates was not correlated with the increase of interest rates. Nevertheless, the authors definitely declare, that "a public debt overhang does slow down the annual rate of economic growth". Eberhardt and Presbitero (2015) found "some support for a negative relationship between public debt and long-run growth across countries" in a large panel analysis of countries. It is necessary to draw attention to extremely valuable empirical research and findings obtained by these two authors as well as to the fact that a lot of macroeconomic and institutional variables were left by them out of sight. This was also pointed out by other researchers (Herndon, Ash \& Pollin, 2014).

Mbate (2013) discovered by panel analysis that domestic debt is crowding out private sector credit, deterring capital accumulation and private sector growth. The need for the enhanced credit availability and fiscal discipline is pointed out as a counteraction for such consequences. The impact of private sector debt on GDP growth was critically evaluated by Barnes (2016) in the context of liberal growth model. She found no proof of private debt positive influence on GDP.

Kong, Glascock and Lu-Andrews (2016) using a dynamic panel data found that real estate investments have significantly positive contemporaneous and negative lagged effects on GDP.

The literature analysis revealed that public debt and private debt, and house prices influence on the GDP growth is widely analysed, but the results obtained are contradictory and the existence of additional factors of economic 
environment can be found. Most of the research is concentrated on the influence of one factor on the economic growth - public debt, private debt, or housing prices. Influence of these factors on the economic growth in some cases was found positive until one threshold, in other cases - until the other thresholds.

The scientific problem which determines the objective and the aim of this paper is defined by the following circumstances. The European Union and especially the EURO zone is a unique multi-country group with one central bank operating not as usual central bank of separate country. The mission of the European Central Bank (ECB) is to maintain the stability of the currency and is not to be as a lender of the last resort for the countries of the monetary union. This is a very important factor in defining the role of public debt in economic growth, but it is not adequately evaluated in published research yet. No research of integrated influence of public debt, private debt and house prices on the GDP growth has been done so far.

The main objective of this paper is to research the influence of public debt, private debt and house prices dynamics on the GDP growth in the European Union countries.

The aim of this paper is to perform a panel data analysis of the influence of change in public debt and in private debt, and house prices on the GDP in the selected European Union countries.

The influence of change in public debt and private debt, and house prices on the GDP: a brief review

Mostly the influence of change in public debt and private debt, and house prices on the GDP was analysed concentrated on separated factors, and we will briefly review the literature.

\section{Public Debt}

Dreger and Reimers (2013) in their analysis added the influence of banking institutional structure impact on the public debt to GDP ratio influence on the real per capita GDP growth for Euro area countries and GDP growth for non-euro area industrial countries. They found, that when the nominal interest rate exceeds nominal GDP growth, the negative influence of this on the economy is obvious for the Euro area countries and is positive for non-euro area industrial countries.

Additional risks resulted from the membership of the country in monetary union may be overcome by creating fiscal union with common liability for national debt of participating in monetary union countries (Dreger \& Reimers, 2013).

Other researchers added some more light on the problem and found that for developed OECD countries increases in public debt is often followed by low real growth and there exist bidirectional causality from low growth to debt accumulation (Donayre \& Taivan, 2017).

Additional factors influencing debt - GDP relation were revealed by the observations of the impacts of country risk indices on the debt influence on growth in a panel data framework which revealed that under a high risk environment, raising public debt is damaging the economic growth (Chiu \& Lee, 2017).
Panel data analysis over the period 1990-2007 of less developed countries provided by Presbitero (2012) shoved that public debt has a negative impact on output growth until it reaches 90 per cent of the GDP, so opposing the results obtained by Reinhart and Rogoff (2012).

Chen and Imrohoroglu (2017) used, instead of statistical methods, the neoclassical growth model to forecast public debt, budget deficits, and output in the US economy under different tax policies. They found that if debt to GNP ratio exceeds $100 \%$, then labour income tax rates higher than $40 \%$ are needed to solve debt problem in the long run, but it will cause about $10 \%$ lower per capita GNP.

Lee, Park, Seo and Shin (2017) analysing the ReinhartRogoff dataset, they found a debt threshold not $90 \%$ but around $30 \%$, above which the median real GDP growth falls abruptly, 1 percentage point lower at the median.

Nguyen, Suardi and Chua (2017) showed the existence of factors influencing public debt and GDP interaction which are hidden in the business environment dynamics. They found "that the U.S. public debt was sustainable until 2005 when the primary surplus to GDP reacted negatively to the debt/income ratio. This is further exacerbated during the global financial crisis when primary surpluses continued to fall with increased debt."

Reinhart and Rogoff (2011a), (2011b) examined data from the nineteenth century to 2010. They found, that domestic debt accounts for almost two-thirds of public debt and this explains why countries default on external debts at seemingly low debt thresholds. They observed that in some cases, the domestic debt is eliminated through high inflation, in other cases, governments default on external debt. According to the authors many governments and multilateral institutions are lacking transparency in making public current situation and history of domestic debt, and are trying to sell debt in foreign markets. So, the unique analysis of historical data provided by Reinhart and Rogoff (2011a), (2011b) explains how bankruptcies of entire countries influence interaction between debt and economic growth. Reinhart and Rogoff (2014) significantly extended their extremely valuable historical research and proved that serial default is a nearly universal phenomenon, as countries struggle to transform themselves from emerging markets to advanced economies. Distance of some years from one to other default create "illusion that "this time is different" among policymakers and investors".

Siddique, Selvanathan and Selvanathan (2016) noticed that external debt growth of poor countries was relied with the surplus revenue produced by the growth of oil price first and the decline of oil price later and incapability of these countries to service debt.

Wang (2017) using a dynamic panel distributed lag model came to a conclusion that there is little direct evidence about exogenous shocks and their transmission in emerging markets, so essentially opposing findings of other researchers.

Gomez-Puig and Sosvilla-Rivero (2017) used a timeseries analysis for each EMU country in years 1961-2015 and discovered that increase of debt begins to have detrimental effects on growth well before a debt ratio of 
around $40 \%$ and $50 \%$ in central and peripheral countries, respectively is reached.

Koh (2017) used structural panel vector auto regression model for identifying a shock to fiscal spending and discovered that fiscal multipliers are larger in advanced economies, when public debt is low.

Miyamoto and Nguyen (2017) analysed business cycles in both small developed and developing countries, and discovered that common disturbances explain one third of the fluctuations in small open economies, especially during important worldwide phenomena.

Konstantakis, Papageorgiou, Michaelides and Tsionas (2015) suggest "that Social Benefits, Social Transfers and Gross Debt are the most significant policy variables with a counter-cyclical character, while taxation was found to have a destabilizing effect". This is opposite to Chen and Imrohoroglu (2017) findings.

\section{Private Debt}

Mian, Sufi and Verner (2017) when analysing panel of 30 countries from 1960 to 2012 found negative relationship between the increases in the household debt to GDP ratio and GDP growth, and that this relationship is stronger for countries with less flexible exchange rate regimes.

Puente-Ajovin and Sanso-Navarro (2015) examined Granger causality between debt and growth in 16 OECD countries in years 1980-2009. The structure of debt - public debt, non-financial corporate and household debt was also analysed. They found that all these types of debt have Granger causality to growth.

Adema and Pozzi (2015) found that the household saving ratio is countercyclical.

Ayala, Canto and Rodrigurez (2017) proved that the relationship between labour macroeconomic indicators and poverty seems to have become weaker recently.

\section{House Price}

Miller, Peng and Sklarz (2011) empirically researched influence of predictable and unpredictable house price changes on economic growth, and identified the collateral and wealth effects of house prices change. They found significant effects of house price change influence on economic growth measured by Gross Metropolitan Product, and discovered that the collateral effect is about three times stronger than the wealth effect, and is lasting for two years, having peak in one year.

Otto (2007) studied unemployment, population growth, mortgage rate, inflation rate, and price-to-rent ratio influence on real house prices in Australia. Only mortgage rate was found to have significant influence on house price growth rates. Other factors could explain 40 to 60 per cent variation of house prices.

Lai and Van Order (2010) analysed the bubble in property values across cities in the United States over the period of 1999-2005. Before the bubble which developed after 2003, price changes were reasonably well explained by the fundamentals, determined for the period of 1980-2005, particularly the decline in long-term interest rates in the early part of the bubble period. Sharp acceleration in house prices coincided with a sudden decrease in short-term interest rates, relative to long rates, what stimulated purchase of housing, and it created a new class of homeowners, discounting at low short-term rates and with questionable qualifications. This created a large shock to the economy.

Pan and Wang (2013) examined the effects of house prices on bank instability and proved the existence of income growth threshold effects in the relationship between house prices and banks instability. They used the house price changes and price deviations from long-run equilibrium and found two income growth thresholds.

Peng, Paul and Muller (2014) used time-warping models for modelling longitudinal growth trajectories for house prices and other phenomena, where temporal setbacks and deflation may be encountered, by decomposing such trajectories into two components. A first component is underlying steady growth driven by inflation and a second - boom-bust component is implemented as time warping. They found indications that the last component is related to market-specific growth rates.

Gholipour, Al-Mulali and Mohammed (2014) analysed the interrelationship between FDI in the real estate sector, economic growth, and property prices while controlling for interest rate and inflation by applying a panel cointegration technique. Their empirical results showed that FDI in real estate do not cause property price appreciations and also do not contribute to economic growth in OECD countries in the short run and in the long run.

Ali and Zaman (2017) assessed panel relationship between house prices and stock prices in 22 European Union countries in years 2007-2012. They found that there are 5 countries which have negative correlation between house prices and stock prices and 15 countries with positive relationship between the variables.

An, Deng, Fisher and Hu (2016) discovered cyclicity in real estate rents growth, generally lagging behind the GDP growth.

Bates and Santerre (2016) analysed elasticity of the market demand for real estate in relation to the real estate price, income and business cycle fluctuations

Liu F., Liu D., Malekian, Li and Wang (2017) using real estate value determined by the economic fundamentals have created real estate bubble size measurement model based on the panel data analysis. Applying this model for housing prices they discovered, that overvaluation of housing prices in China is much smaller than that in 1980s Japan.

Hoffmann, Krause and Laubach (2012) analysed changes in expected house price growth relation to changes in real house price and influence of these variables on aggregate income.

Fuerst and Matysiak (2013) found that lagged GDP, government bond rates and stock returns growth are positive predictors of real estate fund performance.

\section{Data and Methodology}

We used Eurostat data with 24 cross-sections for the years of 2004-2016, total 298 observations of annual data for the panel data analysis of the influence of change in public debt and private debt, and house prices on the GDP in the European Union countries. Countries and periods were selected on the basis of data availability, the size and the level of countries integration into the European 
economy. They are listed in Figures 1 and 2. Euro zone countries Cyprus, Malta and Luxembourg were excluded from the panel due to specific fluctuations of their small economies caused by the highly volatile influence of offshoring financial services on their GDP dynamics. NonEurozone countries: Bulgaria, Czech Republic, Denmark, Hungary, Poland, Romania, Sweden and United Kingdom were included because of high level of their integration to the European Union economy.

Gomez-Puig and Sosvilla-Rivero (2017) used a timeseries analysis for each EMU country for the years 19612015 and discovered that a debt increase begins to have detrimental effects on growth well before a debt ratio of around $40 \%$ and $50 \%$ in central and peripheral countries, respectively is reached.

In our paper we apply panel data analysis to find out complex influence of change in public debt and private debt, and house prices on the GDP in the European Union countries

Using i to subscript the cross section, here, a country, and $\mathrm{t}$ to subscript the time period, the equation for a regression line is as:

$$
y_{i t}=a_{i}+\beta x_{i t}+u_{i t}
$$

Where:

$y_{i t}$ is a dependent variable, here, GDP;

$x_{i t}$ is an independent variable;

$a_{i}$ is a separate intercept for each country, or, another words, cross section fixed effects, partly reflecting the existence of unobservable variable $z_{i}$ which is unique for each country and is not dependent on the time in the limits of analysed period.

$u_{i t}$ is an error term similarly reflecting both, cross country and cross period fixed effects.

Such method enables us to calculate functions using panel least squares and autoregressive AR(p) model and cross-section and period both fixed by dummy variables.

\section{Data Analysis and Results}

Using estimation equation:

$\mathrm{GDP}=\mathrm{C}(1)+\mathrm{C}(2) * \mathrm{GOVGR}$ DEEBT $+\mathrm{C}(3) * \mathrm{PRD}$ _GDP(3) + C(4)*HPR_IND_DEFL(-2) + [CX=F, PER=F]

Where (in this and other equations):

$\mathrm{C}(\mathrm{n})$ are the coefficients of the linear regression equation based on panel least squares and autoregressive $\mathrm{AR}(\mathrm{p})$ model estimation;

GOVGR_DEBT is general government gross debt, consolidated - \% of GDP;

PRD_GDP(3) is private sector debt, consolidated - \% of GDP, lagging by 3 years;

HPR_IND_DEFL(-2) is average annual house price index, deflated, leading by 2 years.

Lagged variables are used for the evaluation of autocorrelation effects. We have tried differently lagged variables for finding best fit equations. On the basis of such selection we calculated regression coefficients ant other statistics presented in Tables 1 to 4 .
Table 1

\section{The Estimation Output for PRD_GDP(3) and HPR_IND_DEFL(-2)}

Dependent Variable: GDP

Method: Panel Least Squares

Sample (adjusted): 20062013

Periods included: 8

Cross-sections included: 24

Total panel (unbalanced) observations: 178

\begin{tabular}{lrrrr}
\multicolumn{1}{c}{ Variable } & Coefficient & Std. Error & t-Statistic & Prob. \\
\hline C & 99.18061 & 5.303020 & 18.70267 & 0.0000 \\
GOVGR_DEBT & -0.202627 & 0.026831 & -7.551971 & 0.0000 \\
PRD_GDP(3) & 0.136826 & 0.030045 & 4.554069 & 0.0000 \\
HPR_IND_DEFL(-2) & -0.042675 & 0.022622 & -1.886455 & 0.0612 \\
\hline R-squared & 0.694371 & Mean dependent var & 101.7910 \\
Adjusted R-squared & 0.624332 & S.D. dependent var & 5.489376 \\
S.E. of regression & 3.364538 & Akaike info criterion & 5.434510 \\
Sum squared resid & $\mathbf{1 6 3 0 . 0 9 6}$ & Schwarz criterion & 6.042267 \\
Log likelihood & -449.6714 & Hannan-Quinn criter. & 5.680972 \\
F-statistic & 9.913942 & Durbin-Watson stat & 0.713504 \\
Prob(F-statistic) & 0.000000 & &
\end{tabular}

The estimation output in Table 1 gives us substituted coefficients for the equation:

GDP $=99.18061-0.202627 *$ GOVGR_DEBT + $0.136826 *$ PRD GDP(3) $-0.042675 *$ HPR IND_DEFL(-2) $+[\mathrm{CX}=\mathrm{F}, \mathrm{PER}=\mathrm{F}]$

As can be observed from Table 1 here we got the best fit using the criterion of minimal sum squared residuals, but not the best R- squared. Graphical illustration of the model is showed in Figure 1.

Using estimation equation:

$\mathrm{GDP}=\mathrm{C}(1)+\mathrm{C}(2) * \mathrm{GOVGR} \_\mathrm{DEBT}+\mathrm{C}(3) * \mathrm{PRD}$ $\mathrm{GDP}+\mathrm{C}(4) * \mathrm{HPR}$ IND_DEFL $+[\mathrm{CX}=\mathrm{F}, \mathrm{PER}=\mathrm{F}]$

Table 2

The Estimation Output for PRD_GDP and HPR_IND_DEFL

\begin{tabular}{|c|c|c|c|}
\hline \multirow{2}{*}{\multicolumn{4}{|c|}{ Dependent Variable: GDP }} \\
\hline & & & \\
\hline \multicolumn{4}{|c|}{ Method: Panel Least Squares } \\
\hline \multicolumn{4}{|c|}{ Sample: 20042016} \\
\hline \multicolumn{4}{|l|}{ Periods included: 13} \\
\hline \multicolumn{4}{|c|}{ Cross-sections included: 24} \\
\hline \multicolumn{4}{|c|}{ Total panel (unbalanced) observations: 298} \\
\hline Variable & Coefficient & Std. Error t-Statistic & Prob. \\
\hline$\overline{\mathrm{C}}$ & 90.58394 & $4.774821 \quad 18.97117$ & 0.0000 \\
\hline GOVGR_DEBT & -0.192431 & $0.031101-6.1873$ & 0.0000 \\
\hline PRD_GDP & 0.095928 & $0.022938 \quad 4.181977$ & 0.0000 \\
\hline HPR_IND_DEFL & 0.099942 & $0.025133 \quad 3.976527$ & 0.0001 \\
\hline R-squared & 0.702624 & Mean dependent var & 102.2695 \\
\hline Adjusted R-squared & 0.658994 & S.D. dependent var & 8.361909 \\
\hline S.E. of regression & 4.882997 & Akaike info criterion & 6.130875 \\
\hline Sum squared resid & 6175.509 & Schwarz criterion & 6.614723 \\
\hline Log likelihood & -874.5004 & Hannan-Quinn criter. & 6.324555 \\
\hline F-statistic & 16.10401 & Durbin-Watson stat & 0.298805 \\
\hline Prob(F-statistic) & 0.000000 & & \\
\hline
\end{tabular}

As can be observed from Table 2 we got the best fit using the criterion of Durbin-Watson statistics, but not the best R- squared. And much higher sum squared residuals.

Using estimation equation:

$\mathrm{GDP}=\mathrm{C}(1)+\mathrm{C}(2) *$ GOVGR_DEBT $(1)+$ $\mathrm{C}(3) *$ PRD_GDP(1) + C(4)*HPR_IND_DEFL + [CX=F, $\mathrm{PER}=\mathrm{F}]$ 
The Estimation Output for GOVGR_DEBT(1) PRD_GDP(1) and HPR_IND_DEFL

Dependent Variable: GDP

Method: Panel Least Squares

Sample (adjusted): 20042015

Periods included: 12

Cross-sections included: 24

Total panel (unbalanced) observations: 274

\begin{tabular}{lrrrr}
\multicolumn{1}{c}{ Variable } & Coefficient & Std. Error & t-Statistic & Prob. \\
\hline C & 89.79395 & 4.367904 & 20.55768 & 0.0000 \\
GOVGR_DEBT(1) & -0.163350 & 0.028994 & -5.633916 & 0.0000 \\
PRD_GDP(1) & 0.069421 & 0.023298 & 2.979699 & 0.0032 \\
HPR_IND_DEFL & 0.116899 & 0.022964 & 5.090521 & 0.0000 \\
\hline R-squared & 0.694878 & Mean dependent var & 101.4891 \\
Adjusted R-squared & 0.647042 & S.D. dependent var & 7.438763 \\
S.E. of regression & 4.419391 & Akaike info criterion & 5.937957 \\
Sum squared resid & 4609.321 & Schwarz criterion & 6.439048 \\
Log likelihood & -775.5001 & Hannan-Quinn criter. & 6.139082 \\
F-statistic & 14.52601 & Durbin-Watson stat & 0.460388 \\
Prob(F-statistic) & 0.000000 & &
\end{tabular}

As can be observed from Table 3 we got lower the criterion of F-statistic and Durbin-Watson statistics, but little bit better sum squared residuals.

Using estimation equation:

$\mathrm{GDP}=\mathrm{C}(1)+\mathrm{C}(2) * \mathrm{GOVGR}$ _DEBT $(2)+$ C(3)*PRD_GDP(2) + C(4)*HPR_IND_DEFL + [CX=F, $\mathrm{PER}=\mathrm{F}]$

\section{The Estimation Output for GOVGR_DEBT(2) PRD_GDP(2)} and HPR_IND_DEFL

Dependent Variable: GDP

Method: Panel Least Squares

Sample (adjusted): 20042014

Periods included: 11

Cross-sections included: 24

Total panel (unbalanced) observations: 250

\begin{tabular}{|c|c|c|c|}
\hline Variable & Coefficient Std. Error & Stat & I \\
\hline$\overline{\mathrm{C}}$ & 85.972773 .810981 & 22.55922 & 0.0000 \\
\hline $\mathrm{T}(2)$ & -0.120786 & & \\
\hline $\mathrm{PRD}_{-}$ & & & U. \\
\hline HPR_I & $\begin{array}{lll}0.146613 & 0.019904\end{array}$ & 7.366179 & 0. \\
\hline$\overline{\mathrm{R}-\mathrm{sq}}$ & \multicolumn{2}{|c|}{$\mathbf{0 . 7 1 8 6 3 5}$ Mean dependent var } & \\
\hline Adjusted R-squared & \multicolumn{2}{|c|}{ 0.671080 S.D. dependent var } & $00 /$ \\
\hline & \multicolumn{2}{|c|}{ 3.793810 Akaike info criterion } & 5. \\
\hline Sum s & \multicolumn{2}{|c|}{ 3065.707 Schwarz criterion } & 6.1616 \\
\hline Log likeliho & \multicolumn{2}{|c|}{-668.0562 Hannan-Quinn criter } & 5.850208 \\
\hline F-statistic & \multirow{2}{*}{\multicolumn{2}{|c|}{$\begin{array}{l}\text { 15.11174 Durbin-Watson stat } \\
0.000000\end{array}$}} & 0.394140 \\
\hline Prob(F-statistic) & & & \\
\hline
\end{tabular}

As can be observed from Table 4 we got better the criterion of F-statistic and lower Durbin-Watson statistics, but not as good, as in Table 1, sum squared residuals. This table presents also the best R-squared, better t-Statistic, and good enough Akaike info criterion. Graphical illustration of the model is showed in Figure 2.

The estimation output in Table 4 gives us substituted coefficients for the equation:

GDP $=85.97277-0.120786 *$ GOVGR_DEBT $(2)+$ $0.049914 *$ PRD_GDP $(2)+0.146613 *$ HPR_IND_DEFL + $[\mathrm{CX}=\mathrm{F}, \mathrm{PER}=\mathrm{F}]$

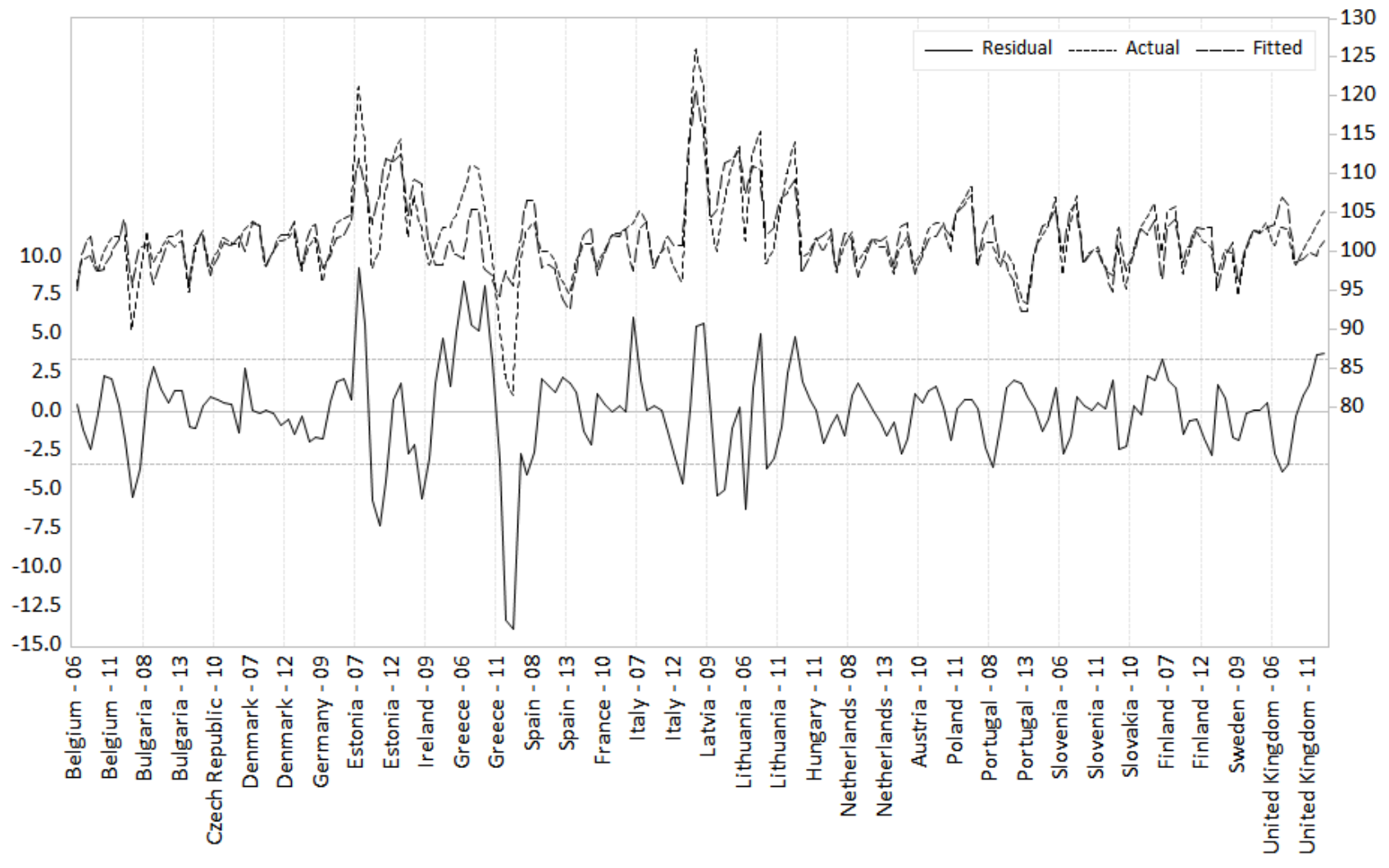

Figure 1. Actual, Fitted, Residual for PRD_GDP(3) and HPR_IND_DEFL(-2) 


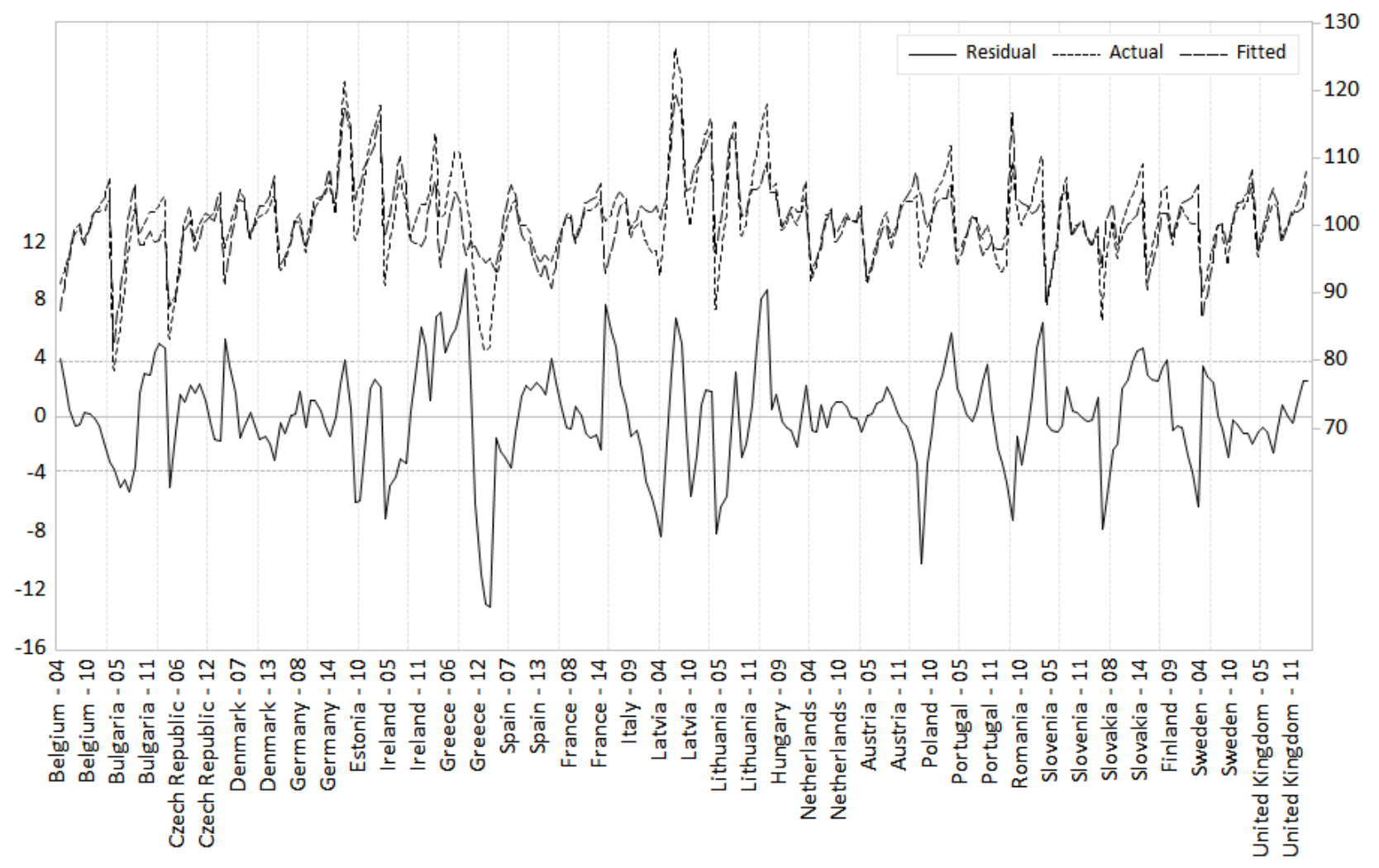

Figure 2. Actual, Fitted, Residual for GOVGR_DEBT(2) PRD_GDP(2) and HPR_IND_DEFL

\section{Conclusions}

The panel data analysis of the influence of change in real public debt and real private debt, and deflated house prices on the GDP in the European Union countries, based on least squares and autoregressive $\mathrm{AR}(\mathrm{p})$ model and crosssection and period both fixed by dummy variables confirmed strong negative correlation between public debt with zero, one and two years lags with the GDP as dependent variable.

This is not surprising having in mind limited functions of the European central bank as a lender of the last resort for the countries of the monetary union, so, for the most of the analysed countries. Private debt has definite positive influence, when measured with zero, one, two and three years lags, but the regression coefficient is 2-3 times lower than the absolute value of the negative influence of public debt on the GDP. These results do not contradict the results received by Dreger and Reimers (2013) who found that Euro area membership do affect the relation between the GDP growth and public debt when the nominal interest rate exceeds nominal GDP growth and the negative influence of public debt growth on the economy is obvious. Our results allowed to obtain a more general conclusion. In the European Union countries the negative influence of public debt growth on the economy is significant when evaluated using zero, one and two year's lags without taking into account the influence of interest rates growth.

House prices unlagged have similar absolute value coefficient of positive influence on the GDP as is absolute value of negative influence of lagged public debt. However, house prices leading by 2 years have negative influence on the GDP, but almost this influence is 5 times weaker than the negative influence of unlagged public debt. We suggest that the transition of the European Union countries to the fiscal union can significantly improve their economic growth perspectives.

The results received are of stochastic character and by no means causative relations, but can be useful for the forecasting purposes.

\section{References}

Adema, Y., \& Pozzi, L. (2015). Business cycle fluctuations and household saving in OECD countries: A panel data analysis. European Economic Review, 79, 214-233. https://doi.org/10.1016/j.euroecorev.2015.07.014

Ayala, L., Canto, O., \& Rodrigurez, J. G. (2017). Poverty and the business cycle: A regional panel data analysis for Spain using alternative measures of unemployment. Journal of Economic Inequality, 15(1), 47-73. https://doi.org/10.10 07/s10888-016-9343-5 
Ali, G., \& Zaman, K. (2017). Do house prices influence stock prices? Empirical investigation from the panel of selected European Union countries. Economic Research-Ekonomska Istrazivanja, 30(1), 1840-1849. https://doi.org/10.1080/13 31677X.2017.1392882

An, X. D., Deng, Y. H., Fisher, J. D., \& Hu, M. R. (2016). Commercial real estate rental index: A dynamic panel data model estimation. Real Estate Economics, 44(2), 378-410. https://doi.org/10.1111/1540-6229.12101

Barnes, L. (2016). Private debt and the anglo-liberal growth model. Government and Opposition, 51(4), 529-552. https://doi.org/10.1017/gov.2015.17

Bates, L. J., \& Santerre, R. E. (2016). The market demand characteristics associated with real estate services: Some evidence from a panel data set of MSAs. Journal of Real Estate Finance and Economics, 53(1), 77-89. doi:10.1007/s11146-0159522-3. https://doi.org/10.1007/s11146-015-9522-3

Chen, K. J., \& Imrohoroglu, A. (2017). Debt in the US economy. Economic Theory, 64(4), 675-706. https://doi.org/10.1007/s00199-015-0908-5

Chiu, Y. B., \& Lee, C. C. (2017). On the impact of public debt on economic growth: Does country risk matter? Contemporary Economic Policy, 35(4), 751-766. https://doi.org/10.1111/coep.12228

Donayre, L., \& Taivan, A. (2017). Causality between public debt and real growth in the OECD: A country-by-country analysis. Economic Papers, 36(2), 156-170. https://doi.org/10.1111/1759-3441.12175

Dreger, C., \& Reimers, H. E. (2013). Does euro area membership affect the relation between GDP growth and public debt? Journal of Macroeconomics, 38, 481-486. https://doi.org/10.1016/j.jmacro.2013.07.012

Eberhardt, M., \& Presbitero, A. F. (2015). Public debt and growth: Heterogeneity and non-linearity. Journal of International Economics, 97(1), 45-58. https://doi.org/10.1016/j.jinteco.2015.04.005

Fuerst, F., \& Matysiak, G. (2013). Analysing the performance of nonlisted real estate funds: A panel data analysis. Applied Economics, 45(14), 1777-1788. https://doi.org/10.1080/00036846.2011.637898

Gholipour, H. F., Al-mulali, U., \& Mohammed, A. H. (2014). Foreign investments in real estate, economic growth and property prices: Evidence from OECD countries. Journal of Economic Policy Reform, 17(1), 33-45. https://doi.org/10.1080/17487870.2013.828613

Gomez-Puig, M., \& Sosvilla-Rivero, S. (2017). Heterogeneity in the debt-growth nexus: Evidence from EMU countries. International Review of Economics \& Finance, 51, 470-486. https://doi.org/10.1016/j.iref.2017.07.008

Herndon, T., Ash, M., \& Pollin, R. (2014). Does high public debt consistently stifle economic growth? A critique of Reinhart and Rogoff. Cambridge Journal of Economics, 38(2), 257-279. https://doi.org/10.1093/cje/bet075

Hoffmann, M., Krause, M. U., \& Laubach, T. (2012). Trend growth expectations and US house prices before and after the crisis. Journal of Economic Behavior \& Organization, 83(3), 394-409. https://doi.org/10.1016/j.jebo.2012.02.020

Koh, W. C. (2017). Fiscal multipliers: New evidence from a large panel of countries. Oxford Economic Papers-New Series, 69(3), 569-590. https://doi.org/10.1093/oep/gpw066

Kong, Y., Glascock, J. L., \& Lu-Andrews, R. (2016). An investigation into real estate investment and economic growth in China: A dynamic panel data approach. Sustainability, 8(1). https://doi.org/10.3390/su8010066

Konstantakis, K. N., Papageorgiou, T., Michaelides, P. G., \& Tsionas, E. G. (2015). Economic fluctuations and fiscal policy in Europe: A political business cycles approach using panel data and clustering (1996-2013). Open Economies Review, 26(5), 971-998. https://doi.org/10.1007/s11079-015-9345-0

Lai, R. N., \& Van Order, R. A. (2010). Momentum and house price growth in the United States: Anatomy of a bubble. Real Estate Economics, 38(4), 753-773. https://doi.org/10.1111/j.1540-6229.2010.00282.x

Lee, S., Park, H., Seo, M. H., \& Shin, Y. (2017). Testing for a debt-threshold effect on output growth. Fiscal Studies, 38(4), 701-717. https://doi.org/10.1111/1475-5890.12134

Liu, F. Y., Liu, D. Q., Malekian, R., Li, Z. X., \& Wang, D. Q. (2017). A measurement model for real estate bubble size based on the panel data analysis: An empirical case study. Plos One, 12(3). https://doi.org/10.1371/jour nal.pone. 0173287

Mbate, M. (2013). Domestic debt, private sector credit and economic growth in Sub-Saharan Africa. African Development Review-Revue Africaine De Developpement, 25(4), 434-446. https://doi.org/10.1111/1467-8268.12040

Mian, A., Sufi, A., \& Verner, E. (2017). Household debt and business cycles worldwide. Quarterly Journal of Economics, 132(4), 1755-1817. https://doi.org/10.1093/qje/qjx017

Miyamoto, W., \& Nguyen, T. L. (2017). Business cycles in small open economies: Evidence from panel data between 1900 and 2013. International Economic Review, 58(3), 1007-1044. https://doi.org/10.1111/iere.12243

Miller, N., Peng, L., \& Sklarz, M. (2011). House prices and economic growth. Journal of Real Estate Finance and Economics, 42(4), 522-541. https://doi.org/10.1007/s11146-009-9197-8 
Vytautas Snieska, Daiva Burksaitiene. Panel Data Analysis of Public and Private Debt and House Price Influence on ...

Nguyen, T. D., Suardi, S., \& Chua, C. L. (2017). The behavior of US public debt and deficits during the global financial crisis. Contemporary Economic Policy, 35(1), 201-215. https://doi.org/10.1111/coep.12166

Otto, G. (2007). The growth of house prices in australian capital cities: What do economic fundamentals explain? Australian Economic Review, 40(3), 225-238. https://doi.org/10.1111/j.1467-8462.2007.00453.x

Pan, H. R., \& Wang, C. (2013). House prices, bank instability, and economic growth: Evidence from the threshold model. Journal of Banking \& Finance, 37(5), 1720-1732. https://doi.org/10.1016/j.jbankfin.2013.01.018

Peng, J., Paul, D., \& Muller, H. G. (2014). Time-warped growth processes, with applications to the modeling of boom-bust cycles in house prices. Annals of Applied Statistics, 8(3), 1561-1582. https://doi.org/10.1214/14-AOAS740

Presbitero, A. F. (2012). Total public debt and growth in developing countries. European Journal of Development Research, 24(4), 606-626. doi:10.1057/ejdr.2011.62. https://doi.org/10.1057/ejdr.2011.62

Puente-Ajovin, M., \& Sanso-Navarro, M. (2015). Granger causality between debt and growth: Evidence from OECD countries. International Review of Economics \& Finance, 35, 66-77. https://doi.org/10.1016/j.iref.2014.09.007

Reinhart, C. M., \& Rogoff, K. S. (2010). Growth in a time of debt. American Economic Review, 100(2), $573-578$. https://doi.org/10.1257/aer.100.2.573

Reinhart, C. M., \& Rogoff, K. S. (2011a). From financial crash to debt crisis. American Economic Review, 101(5), 16761706. https://doi.org/10.1257/aer.101.5.1676

Reinhart, C. M., \& Rogoff, K. S. (2011b). The forgotten history of domestic debt. Economic Journal, 121(552), 319-350. https://doi.org/10.1111/j.1468-0297.2011.02426.x

Reinhart, C. M., \& Rogoff, K. S. (2014). This time is different: A panoramic view of eight centuries of financial crises. Annals of Economics and Finance, 15(2), 215-268.

Reinhart, C. M., Reinhart, V. R., \& Rogoff, K. S. (2012). Public debt overhangs: Advanced-economy episodes since 1800. Journal of Economic Perspectives, 26(3), 69-86. https://doi.org/10.1257/jep.26.3.69

Siddique, A., Selvanathan, E. A., \& Selvanathan, S. (2016). The impact of external debt on growth: Evidence from highly indebted poor countries. Journal of Policy Modeling, 38(5), 874-894. https://doi.org/10.1016/j.jpolmod.2016.03.011

Wang, Y. B. (2017). How do emerging markets respond to macroeconomic shocks? - dynamic panel evidence on the effects of disasters. Open Economies Review, 28(4), 731-760. https://doi.org/10.1007/s11079-017-9440-5

The article has been reviewed.

Received in January, 2018; accepted in February, 2018. 